\title{
The Nordic geological surveys: Geology for society in practice
}

\author{
1 Geological Survey of Norway (NGU), Leiv Eirikssons vei 39, NO-7491 Trondheim, Norway. E-mail: Morten.Smelror@NGU.NO \\ 2 Geological Survey of Denmark and Greenland (GEUS), Øster Voldgade 10, DK-1350 København K, Denmark. \\ 3 Geological Survey of Sweden (SGU), Box 670, S-751 28 Uppsala, Sweden. \\ 4 Geological Survey of Finland (GTK), P.O. Box 96, FI-02151 Espoo, Finland. \\ 5 Iceland Geosurvey (ISOR), Grensásvegi 9, 108 Reykjavík, Iceland.
}

Since the mid-nineteenth century, when the first of the Nordic Geological Surveys were established, they have generated a substantial amount of information on the Earth's crust, its natural resources, its processes, and on the geological history of Nordic areas. The collective mission of the geological surveys is to carry out "Geology for Society", by doing research and providing services, and by making geological information and data easily accessible to all the varied end users in industry, government agencies, government institutes, public administrations, technical offices, academia and research institutes, as well as for private individuals. The present paper gives a brief overview of a few, selected, research areas and projects currently undertaken by the Nordic geological surveys. These serve as practical examples of how the Nordic geological surveys address important societal problems and challenges that require geological input for their solution.

\section{Introduction}

Most countries in the world have a Geological Survey with a mission to carry out services for the benefit of Society. The Nordic geological surveys (Centers shown in Figure 1) have long traditions of providing, and applying, geological knowledge and data for multiple purposes and needs. The history of the surveys reflects the political and social situation of their host countries over the past 150 years. The oldest, the geological surveys of Norway (NGU) and Sweden (SGU), were established by 1858 , followed by the Finnish survey (GTK) in 1885 and the Danish survey (GEUS) in 1888. The late 19th Century was characterized by notable industrialisation, urbanisation and the development of efficient and modern farming. The surveys were established to meet the rapidly developing needs for more knowledge about national mineral resources, materials for construction and space for agriculture. In contrast to the older surveys, the Iceland GeoSurvey (ÍSOR) was established in 2003, by taking over the responsibilities of the former GeoScience Division of Orkustofnun, the National Energy Authority of Iceland.

When NGU was established in 1858 it was argued to the "Ministry of the Interior" that a national geological survey would be "practically useful, scientifically important, and to the honour of the country" (Børresen and Wale, 2008). The mapping of bedrock, surface deposits and mineral resources has traditionally been the main task of the geological surveys. However, today, they are dealing with almost all aspects related to the need for geological knowledge and information in society, focusing on mineral, water and energy resources, land use and protection, engineering geology, geohazards, environmental and climatic changes, pollution and waste management, as well as geotourism. The Finnish, Icelandic, Norwegian and Swedish surveys are placed under the national ministries of Industry (and Trade), while the Danish survey is responsible to the Ministry of Environment. The present paper gives a brief overview of a few, selected, research areas and projects currently undertaken by the Nordic geological surveys. These serve as practical examples of how the surveys address important societal problems and challenges by conducting geology research for society.

\section{The growing need for minerals}

The markets for minerals and mineral products are to some extent global, particularly those relating to ores and concentrates. There are also local markets for minerals, mainly those of lower value such as aggregate, although these may be transported very long distances. Between these, many minerals, particularly industrial minerals, span regional, national and global markets, being driven, for example, by the building of new infrastructure in emerging economies.

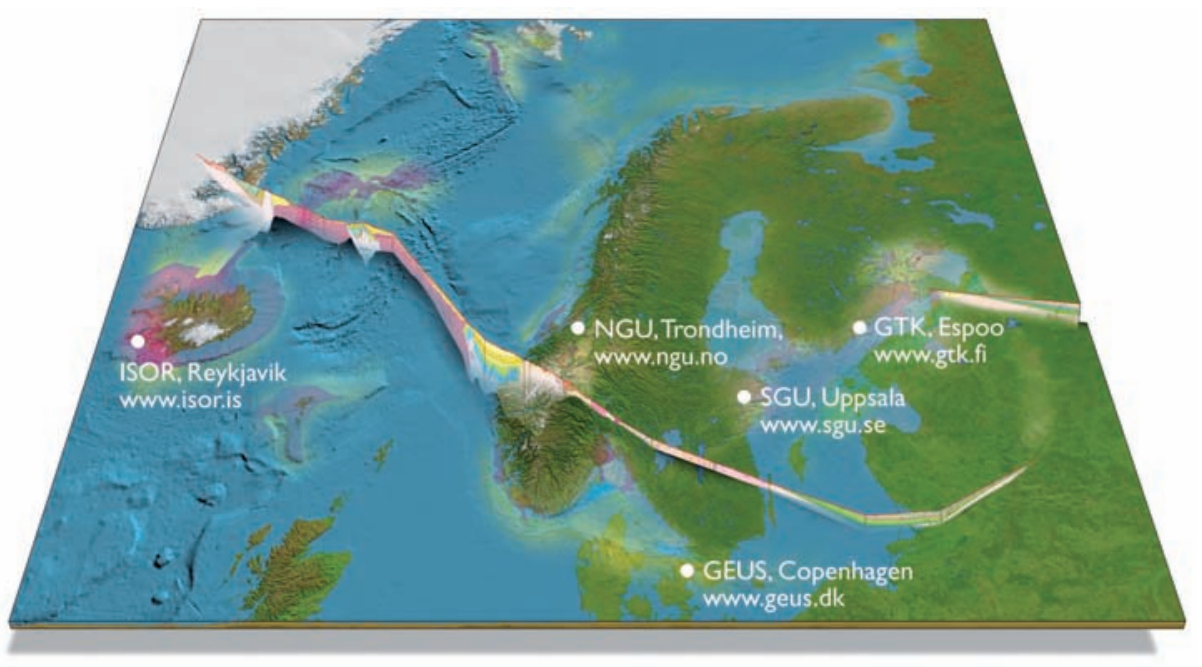

Figure 1 Topographic map of Nordic countries, with locations of the main offices of the Nordic geological surveys. 
The geological conditions for mineral extraction differ between the Nordic countries. In Denmark the products extracted are mainly industrial minerals such as chalk, limestone, clay, quartz sand, expanding clays and moler (diatomaceous minerals), whilst in Greenland the production of olivine is important. Icelandic mineral production includes diatomite, pumice and basalt; the last of these is mainly used for mineral wool production. Thermal energy is a large contributor to Icelandic power supply; it is utilised in the downstream mineral industry for production of aluminium and ferroalloys (ferrosilica), but also for heating. Norway is a major supplier of ilmenite, olivine, nepheline-syenite and quartz, as well as limestone and dolomite (Neeb, 2006). In Finland, the major industrial minerals produced include carbonates, apatite, talc, quartz, feldspar and wollastonite. Swedish industrial mineral production includes carbonates and dolomite, dolerite, quartz, feldspar and clay. Ores mined include those of iron, lead, zinc, copper and gold in Sweden (Figure 2); copper, zinc, nickel and chromite in Finland and iron in Norway.

The use of dimension stone on a global scale has increased steadily. The principal materials extracted in the Nordic countries include granite, schist, sandstone, quartzite, flagstone, marble, limestone and soapstone. Some Nordic stones are internationally famous and include varieties such as Balmoral Red, Baltic Brown, Blue Pearl, Emerald Pearl, Bohus, Vånga and Ebony Black (Selonen and Suominen, 2003).

On-going exploration activities for the future supply of mineral commodities are intense, and mostly undertaken by mining and exploration companies. The Finnish Geological Survey is the only Nordic survey carrying out exploration itself. The role of the other geological surveys is traditionally supportive; they are the national authorities that stand for the geological knowledge and collection of data, which are presented on geological maps and databases. Geophysical and geochemical data are also collected, stored and made available; airborne geophysical data are highly valuable for exploration (Airo, 2005). Some of the surveys have dedicated rock stores where drillcore from exploration is archived and where researchers and exploration geologists can examine core material. Commonly, exploration reports have been archieved and give direct access to information from past exploration operations. Internet services have been developed for the mining sector, and international companies use them actively for fact-finding and data mining (e.g., http://en.gtk.fi/ExplorationFinland/, http://www.prospecting.no and http://www.sgu.se/sgu/en/naturresurs/mininfo/index.html). Information of more common geoscientific interest is made available at the libraries of the geological surveys and at the surveys internet webpages.

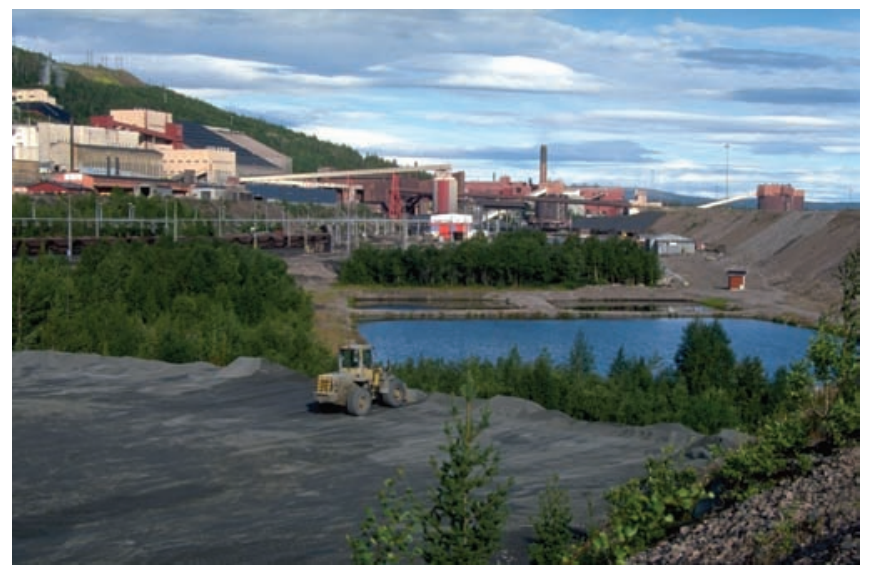

Figure 2 Mineral production at Vitåforsgruvan, Malmberget in Lappland, Sweden (Photo: Anders Damberg).

\section{Geology and land-use}

The surveys have undertaken several studies assessing the suitability of different areas for construction, particularly associated with the planning of geological resources in densely populated areas - for instance where water supply is essential (Neeb, 1996; Nikkarinen et al., 1996; Ojala et al., 2006). The investigations are based on the existing geological mapping data produced by surveys. In Finland, the surficial deposits have been classified according to their known geotechnical properties. Map data are commonly integrated with information on slope steepness, thickness of the fine-grained deposits, clay and silt content, and sometimes with information on bedrock topography as well. The data collected by geological mapping, drilling, airborne electromagnetic measurements, and gravimetric profiling of surficial deposits provide information on the suitability for construction purposes.

Underground construction is of increasing importance because of on-going urbanization; infrastructure, caverns, storages, offices, etc. commonly are built underground. The demand for bedrock investigations, including information on weathering, fractures, joints and faults, is considerable. Bedrock material is increasingly used in infrastructure development as aggregates for roads, railways, concrete and airport runways. SGU has developed so-called Bedrock Quality Maps, now covering large parts of urban areas in central and south Sweden, such as the Stockholm, Lake Mälaren and Göteborg regions. The methodology for production of these is described by Persson and Schouenborg (1996), cf. Persson (2002). A quality classification of bedrock materials is necessary to ensure the correct usage for different purposes. In Scandinavia the use of gravel and sand is to be reduced on environmental grounds, whereas the demand on other materials, such as crushed bedrock, will consequently increase.

Geological maps are being used increasingly in land-use planning. The standard geological map provides regional information on the thickness of surficial deposits - based on boreholes along road and railway lines, and sounding data from shallow surveys. The maps are generally accompanied by written descriptions of the properties of the soils in the area, and tables illustrating soil and groundwater qualities (Neeb, 1996; Nikkarinen et al., 1996). Despite these features, however, the maps are often not readily adaptable for detailed planning purposes. For example, the standard 1:20,000 Finnish geological map (http://geokartta.gtk.fil) has a grid that makes generalizations unavoidable.

The need for more detailed maps, for specific purposes such as construction suitability assessments, has increased. For example, since the 1990s, geological and geotechnical soil maps for building purposes and geological risk evaluation have been made available on the 1:10,000 and 1:4,000 scales in Central Finland and near Helsinki in connection with geotechnical investigations (Neeb, 1996; Nenonen et al., 1999; Ojala et al., 2006). Information relating to soil distribution, for instance geotechnical soil maps at 1:10,000 and 1:2,000 scales, are available for land-use planning purposes in each of the Nordic countries. The geological surveys have produced construction suitability maps, based largely upon slope angles, overburden depths and soil types (Idman et al., 2006). The data collected provide information on suitable foundation types and foundation depths (pile lengths). In Finland, a cost-benefit analysis has shown that piling is economic to a depths of c. $13 \mathrm{~m}$. Geophysical methods (gravimetric measurements and the airborne electromagnetic) allow delineation of local areas, where deep and/or unfavourable foundation conditions occur (Puranen et al., 1999; Ojala et al., 2006) and building costs are greatest. The methodology for producing "suitability maps" for construction purposes is most usefully employed in areas of new construction. Only sparse geotechnical drilling data are needed to evaluate the overall foundation costs of different regional and town plans (Figure 3). One service provides maps that enable planners to evaluate areas susceptible to geological hazards, such as 


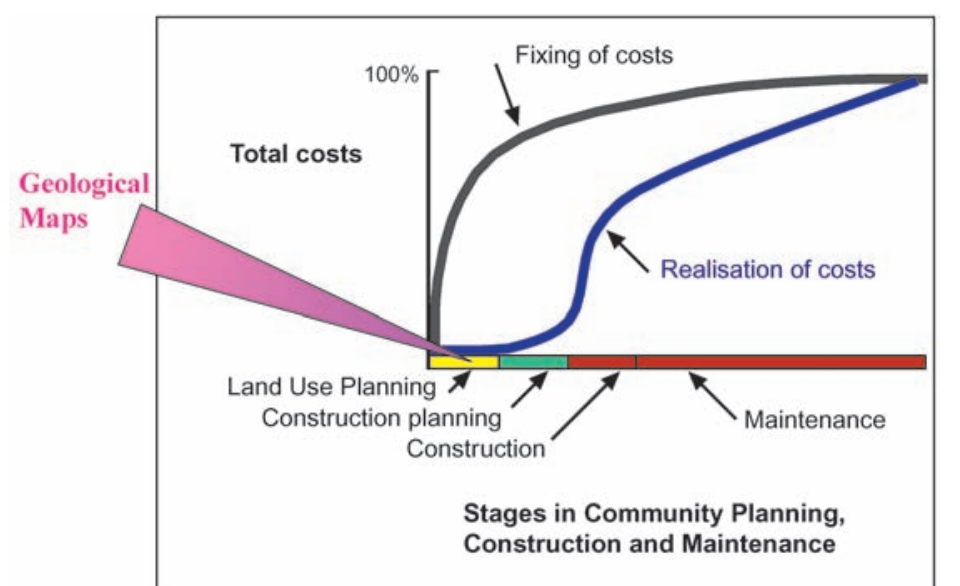

Figure 3 The figure illustrates the overall costs of a construction process. They are firmly fixed in the initial stage of the process, where geology based land-use planning may lead to substantial reduction of construction costs, thus maximizing the impact of geodata for citizens, constructors and society (Idman et al., 2006).

landslides, rock-falls, flooding, erosion, compressive or frostaffected swelling soils, radon risks, etc. In Sweden and Norway, the most detailed regular maps of this type produced by the surveys are at the scale of 1:20,000. The work of both surveys in collaboration with geotechnicians, has resulted in examples of landslide thematic maps (Viberg et al., 2002; see also www.skrednett.no).

The internet has become an increasingly important tool in providing geological information to planners and developers. In the Helsinki area, a completely new geological information system (GeoTIETO) for land use planning is being developed (Wennerström et al., 2006). The basic idea has been to offer users continually maintained and updated geological data and supporting material within any area at the desired scale, directly through an open and free Internet-based portal. The datasets will include geological maps (bedrock maps at 1: 50,000 and Quaternary deposit maps at 1: 20,000 scales), geological models and uniform geological databases such as those based on soils, bedrock drilling, rock aggregates, geophysical data, relief models, topographic maps, aerial photographs and land use information. Users will be able to easily combine and display several data sets, make searches and interpret geological information using a Web browser.

Data from sites have been collected and stored in databases at the geological surveys and are commonly used to develop models or products. In some cases (for example, at SGU) the information from tunnels and caverns has been presented in 3D models (cf. Morfeldt and Persson, 1997; Persson, 1998). Storage of geological and engineering geological information from new sites has to be maintained to ensure the models remain up-to-date.

\section{Developing geothermal energy}

The Nordic countries rely on a diverse spectrum of sources of energy that reflect both the natural resources each country has at hand, as well as what has been developed through political motivation. The national geological surveys have been central in the exploration, development and management of energy resources, including: the large oil and gas reserves in the Nordic seas that Norway and Denmark have been able to develop; coal deposits that are mined on Svalbard; water resources for hydropower which are abundant in Iceland, Norway and Sweden; and geothermal resources that are especially abundant on Iceland.

The geological surveys actively promote and develop new knowledge and technologies for effective and extensive use of geo- thermal energy; in all countries there is increasing use of geothermal energy, both in the public and the private sectors. Iceland is in an unique position owing to its active volcanism, and is leading the development; already more than $70 \%$ of the primary energy use in Iceland comes from hydropower and geothermal energy.

The geological setting of Iceland is unique with a sub-aerial exposure of the Mid-Atlantic Ridge, manifested by active volcanic rift zones extending from northeast to southwest of the island. The active volcanism produces a high heat flow to the surface, caused by magmas emplaced in the upper crust. This heat is extracted from both 'high temperature fields' within the active volcanic zones and 'low temperature fields' outside these zones. The heat is extracted as hot water and steam and is used for district heating, industrial purposes and power generation, offering a cheap and environmentally benign source of energy for the Icelandic society.

From the early stages of exploration to eventual development and production from a geothermal field, the geological survey's involvement is manifold. At the exploration stage, the geological survey makes geological and geothermal maps and conducts geochemical surveys to produce a preliminary model of the geothermal field, the geological and the tectonic setting in order to estimate the temperatures and fluids that may be expected to be found at depth. Complementary geophysical surveys and studies of seismic activity are used to map reservoir boundaries and to outline active tectonic features that may be associated with permeable zones (Eysteinsson et al., 1994). When drilling commences, data from drill cuttings, cores, geophysical logs, fluid samples and flow tests are collected from the wells. These data provide the basis for evaluating the geothermal characteristics and production capacity of each well. Furthermore, they are integrated into a conceptual model of the reservoir that forms the basis for numerical modeling to assess the generating capacity of the field as well as to improve the positioning of new production and injection wells. With production, changes in the geothermal reservoir are continually monitored and evaluated in order to optimise production and enhance the lifetime of the geothermal reservoir (Stefansson et al., 1995; Kristmannsdottir and Armannsson, 1996). Examples of ongoing projects are the Hellisheidi (Figure 4) and the Reykjanes fields in south-western Iceland, where two new geothermal power plants with installed capacity of 90 and $100 \mathrm{MWe}$, respectively, began production in 2006. Drilling is still on-going in the Hellisheidi field to encourage further expansion, while exploration drilling is well underway in northern Iceland in the fields of Krafla, Námafjall and Theistareykir. Meanwhile, exploration and development in the 'low temperature' areas, whilst at a smaller scale, is continuing to increase the percentage of households (currently $89 \%$ ) in Iceland heated by geothermal energy.

With increasing demand for renewable energy, the Nordic geological surveys have in recent years become involved in research and exploration into new resources of geothermal energy through international projects, for example the on-going ENGINE project (ENhanced Geothermal Innovative Network for Europe, engine.brgm.fr). Another major project, IDDP (Iceland Deep Drilling Project, $w w w . i d d p . i s)$, is exploring whether supercritical fluid can be extracted economically from geothermal fields in Iceland (Fridleifsson and Elders, 2005).

The knowledge and experience from exploration and development of geothermal fields in the surveys is extensive and goes back more than 70 years. It is passed-on through scientific training and workshops across the world in order to advance the development of geothermal energy. Since 1979 the United Nation University has been conducting a geothermal training programme in Iceland for professionals from developing countries (Fridleifsson, 2005). By 2006, 359 students from 40 nations had graduated from this programme. 


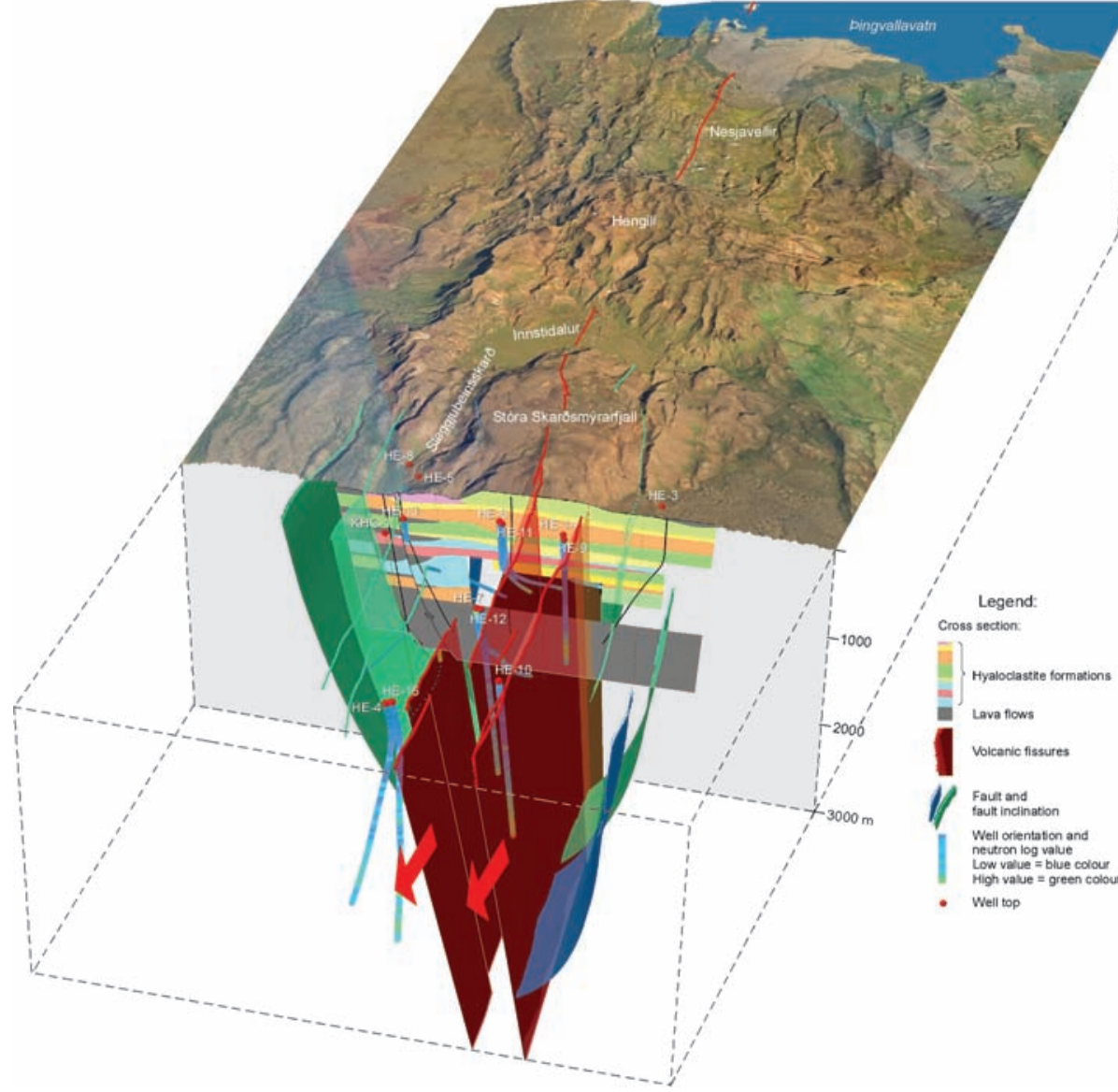

Figure 4 3D geological model of the Hellisheidi geothermal field. The flow of hot geothermal fluids is believed to be mainly towards the northeast and southwest, out from the Hengill central volcano along two eruption fissures, that are, respectively, 2,000 and 5,000 years old (Franzson et al., 2005).

\section{Exploring the sea-floor}

The Nordic countries include extensive coastal and shelf areas with large abiotic and biotic natural resources. The Nordic marine "landscapes" comprise a variety of environments from the intra-cratonic Baltic Sea, via the extensive Norwegian Sea margin, to the deep ocean with active sea-floor spreading in the Norwegian-Greenland-Iceland Sea, and on to the glaciated shelves and coasts of Greenland and Svalbard. For decades the geological surveys have mapped and studied the sea-floor and subsurface, providing key information on the geological history, geological processes and properties of the Nordic coastal and shelf areas (Holtedahl, 1993; Longva and Thorsnes, 1997; Ottesen et al., 2005; Smelror et al., 2007). As exploitation for resources in the Nordic seas increases, there is a rapidly growing need for more knowledge about the natural and human-influenced state of the marine environment-particularly with regard to biological diversity and the state of contamination. The geological surveys provide basic knowledge to ensure that the marine resources are managed in an effective and sustainable way, by providing data on the spatial distribution, quantities and qualities of the resources in the sea and on and below the sea-floor and important knowledge about the natural and man-made processes affecting the marine environment.

One important task is to produce detailed topographic databases and models of the seafloor (Figure 5). These bathymetric maps, combined with information about the sea-bed geology and environment, have multiple applications for the identification of marine habitats (e.g., soft- and hard-ground communities, coral mounds), the exploitation of marine mineral resources, and the planning and installation of sub-sea infrastructures (e.g., pipelines, cables, aquaculture installations and hydrocarbon installations). Examples of on-going projects are the international GeoHab-project (www.ngu.no/geohab/), the EU Inter-regional Balance project (www.balance-eu.org/), the Finnish Inventory Programme for the Underwater Marine Environment (VELMU) in the sea areas of Finland, and the Norwegian Mareano-program in the Barents Sea and the northern Norwegian Sea (www.mareano.no).

In recent years, the geological surveys have also focused on studies of the interaction between changes in the Quaternary climate, sedimentary processes and ocean circulation in the Nordic and North Atlantic waters (Rise et al., 2005; Nyberg et al., 2007). Other climate-related research projects deal with both Arctic and low-latitude marine environments and the possible role of climate change in these areas for forcing NW European climate.

The marine geology research of the Nordic surveys also includes investigations of

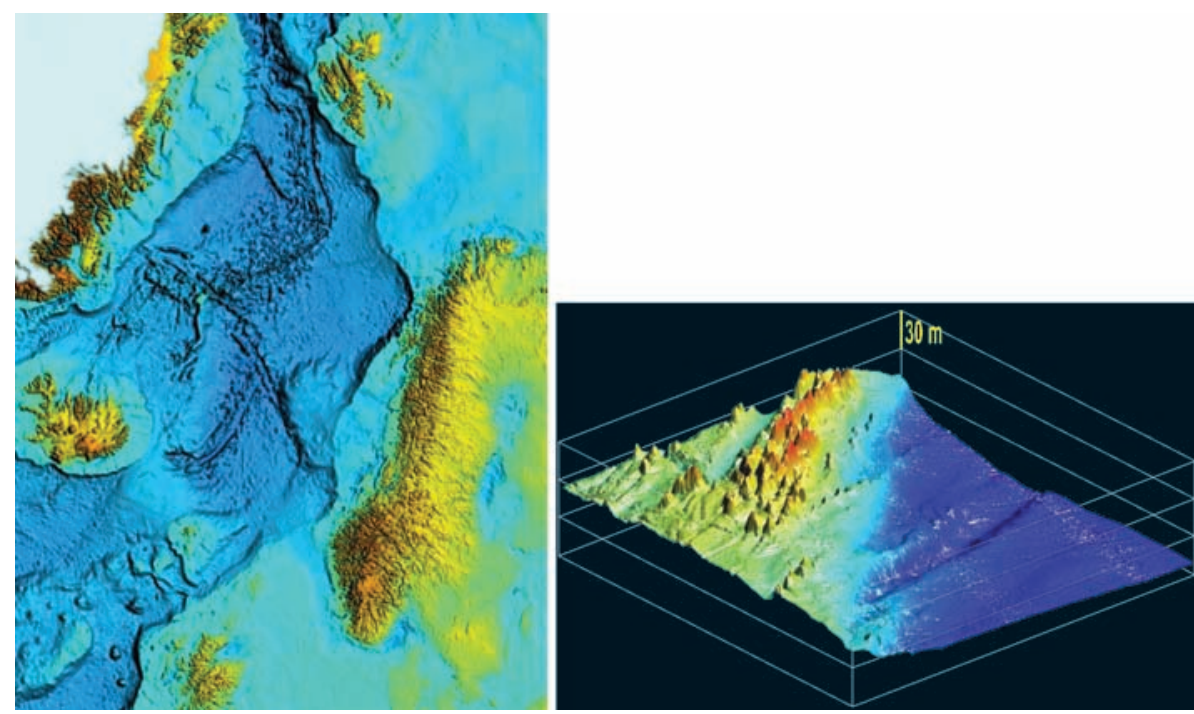

Figure 5 The Sula reef is one of the many large cold-water coral reefs that in recent years have been mapped on the Mid-Norwegian shelf (Thorsnes and Fossä, 2004). The coral reefs are amongst our richest marine habitats, and for several commercially important fish stocks, the reefs are very important spawning and breeding grounds. Significant amounts of coral reefs and other habitats are already damaged by human activities, in particular trawling with heavy equipment. 
coastal erosion processes, shelf stratigraphy, and potential geohazards in the fjords, on the shelf and in deep-water areas of interest for offshore hydrocarbon exploitation (Rise et al., 2006). One key project has been on developing a geological model for the Ormen Lange area; i.e., an integrated geological and geotechnical study for the safe development of the Ormen Lange gas field within the giant Storegga submarine slide complex.

\section{On unstable ground}

Natural hazards, including geohazards, pose constant risks to human life and infrastructure. Landslides, rockfalls, avalanches and flooding represent the most common types of natural hazard in those Nordic countries where the bedrock is dominated by the tectonically stable Baltic Schield. Whilst on Iceland, with its position on the MidAtlantic spreading zone, earthquakes and volcanic eruptions also comprise serious threats. The vulnerability of populated areas to natural disaster is partly a consequence of decades of neglect by planning authorities of the dangers of natural hazards. Therefore, it is important to characterize the land areas that potentially are subject to geohazards, and to develop efficient methodologies to incorporate natural disaster reduction into land-use planning and management. In recent years, the Nordic geological surveys have participated in EU-funded projects dealing with geological and technological hazards, such as ESPON, researching natural and technological hazards and risks affecting the spatial development of European regions http://www.espon.eu/ (Schmidt-Thome, 2006) and ARMONIA applied multi-risk mapping of natural hazards for impact assessment http://www.armoniaproject.net (Jarva and Virkki, 2006; SchmidtThome et al., 2006).

One task of the Nordic geological surveys is to develop national databases that include hazard maps, risk maps, geological data, historic volcanic eruptions, earthquakes, avalanche and slide events, geotechnical data and localization of different types of protection work and monitoring. The database is served on the Internet, providing an easy access to digital maps, information on previous hazard areas as well as to hazard assessments

Landslides, rockfalls and avalanches are important geological processes in the Nordic landscape. Slow displacements through time may cause instabilities and bedrock failures. If large rockfalls and landslides run into narrow fjords or alpine lakes they may trigger tsunamis, damaging near-shore settlements and infrastructure (Bøe et al., 2004; Braathen et al., 2006; Harbitz et al., 2006) (Figure 6).

Fine-grained marine sediments cover large lowland areas of middle and eastern Norway, and large areas in southwestern and middle Sweden (also northern Sweden in some valleys) and Finland. Dilution of salt by groundwater flow leads to the formation of quick clay. Such processes may lead to highly unstable conditions and fatal quick-clay slides can occur. Glacial tills on steep mountain slopes may collapse during periods of intense precipitation, triggering debris flows. With changing climatic conditions and more extreme rainfalls in some exposed regions, the frequency of such natural hazards is expected to increase in the years to come.

Earthquakes occur in response to stress-release due to movement of the Earth's lithospheric plates, and are particularly abundant in the plate-boundaries. The divergent plate boundary between the North American and Eurasian plate (the Mid-Atlantic Ridge) transects Iceland from southwest to northeast, forming an active volcanic rift zone, where seismic activity occurs on a daily basis, and where volcanic eruptions take place every few years (Figure 7). Large destructive earthquakes fortunately are rare and far between; the other Nordic countries are located within the Eurasian plate and, consequently, earthquakes are relatively rare and occur mainly at magnitudes that create little damage. The daily

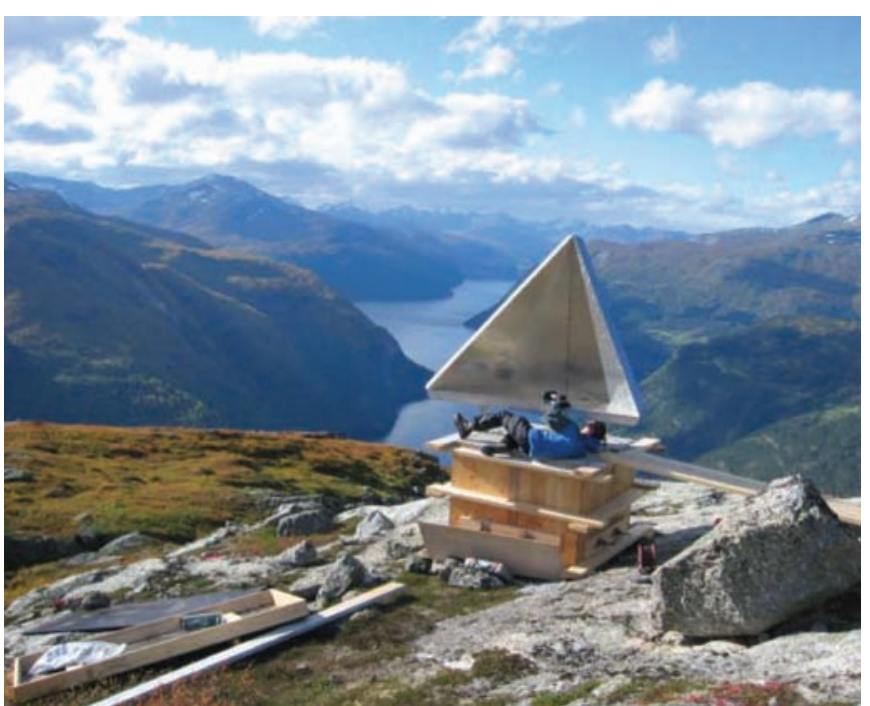

Figure 6 Installation of radar reflectors for monitoring movements of unstable mountains in Storfjorden, western Norway. Rockfalls into fjords and lakes may create large tsunami that will damage the settlements and infrastructure (Photo: Lars H. Blikra).

monitoring of seismic activity is the responsibility of different national agencies (for example, the Metrological Office on Iceland and NORSAR in Norway); however, the geological surveys' expertise is more concerned with risk assessment. Evaluation of the risks from geohazards such as earthquakes and volcanic activity is based principally on reconstruction of previous events, their magnitude and rate of recurrence. Through geological mapping and the dating of such events the record of large destructive earthquakes and volcanic eruptions can be reconstructed. On the foundation of such data, the geological surveys provide estimates of the risk of forthcoming events, their possible magnitude and impact. In societies, where the vulnerability of living on a dynamic earth is well understood, geohazard risk assessments have priority. When making decisions concerning where to plan developments and how to construct or reinforce them, there always has to be a viable balance between the risks, on the one hand, and the social and economic gains, on the other hand.

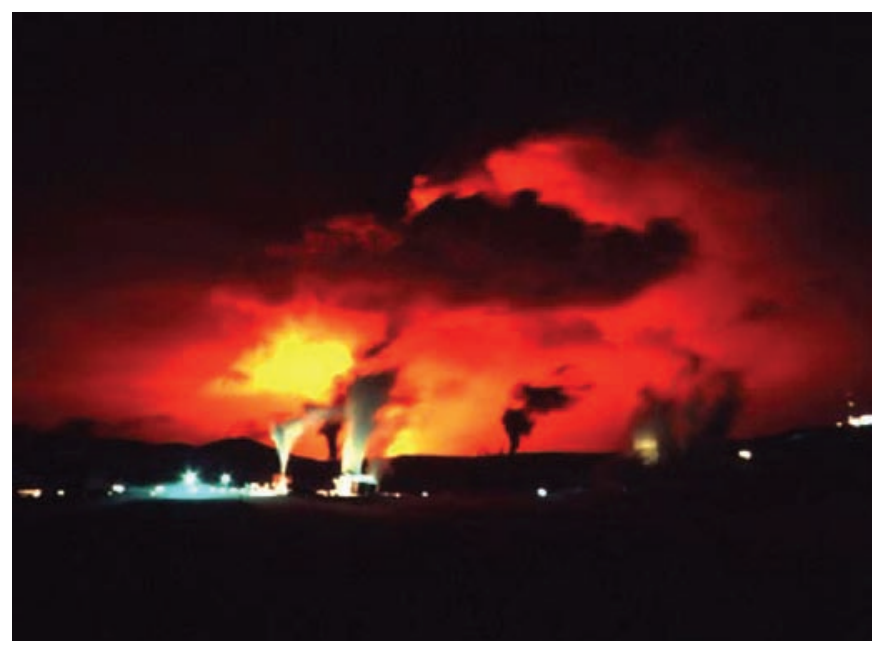

Figure 7 Krafla geothermal power plant during the Krafla fires, 1975-1984. The eruptions slowed down the development of the field for more than 20 years due to volcanic gas contamination of parts of the geothermal field (photo: O. Sigurdsson). 


\section{The melting Arctic}

The Arctic constitutes an important region for the Nordic countries. Consequently, studies of climate and environmental change in the Arctic are among the key research areas of the geological surveys. Nordic mythology and cultural identity is closely tied to the vast northern expanse, originally populated by the Inuit in Greenland and the Sami in Northern Scandinavia. The cold Arctic regions are also home to numerous glaciers and ice caps as well as the second-largest body of ice on Earth, the Greenland ice sheet. This mass of ice covers 1.7 million square kilometers and would cause a global sea-level rise of nearly 7 meters were it to melt away completely.

Instrumental temperature records over the last 100 years indicate a global average rate of warming of $0.74 \pm 0.18^{\circ} \mathrm{C}$. The Arctic seems to be much more sensitive to climate change, as the average arctic temperatures have increased at almost twice the global average rate over the same period (Trenberth et al., 2007). Such a warming has a profound impact on the mass balance of glaciers being associated both with more precipitation and more melting (Figure 8). Understanding the response of glaciers and ice caps to climate change is important to the Nordic geological surveys for several reasons: the contribution of Arctic ice masses to global sea level rise is potentially very large, the changing run-off from glaciated catchments may affect existing or planned hydropower production significantly and, finally, the changing position of the glacier margin may cover or reveal valuable mineral resources. All these aspects are currently under investigation in Greenland by GEUS.

Within the last five years, the Greenland ice sheet has experienced a dramatic loss of mass to the ocean. Observations of elevation change, gravimetrical change and outlet glacier acceleration have all provided strong indications of accelerated loss of ice volume. However, reports on the estimated current mass loss varies from less than 100 cubic kilometers a year to more than three times that value (Alley et al., 2007). This uncertainty means that the accelerated mass loss of the Greenland ice sheet was not explicitly included in the last climate change assessment of the United Nations (the IPCC Report from 2007), but only noted as requiring clarification; a suspected feedback mechanism between increased surface meltwater production due to warming and outlet glacier acceleration was mentioned. A new programme for monitoring of the Greenland ice sheet has now been launched in order to quantify the mass loss on a regular basis (Ahlstrøm et al., 2007). The programme aims at providing the policymakers with the necessary scientific knowledge to make decisions regarding carbon-emissions.

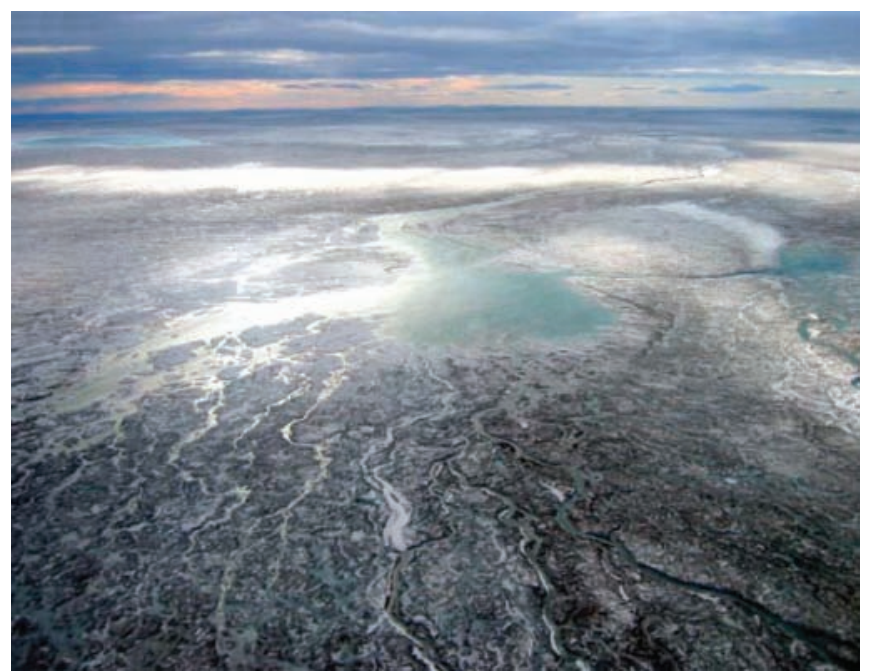

Figure 8 Meltwater lakes forming on the surface of the Greenland ice sheet near Ilulissat, West Greenland. The areal extent of the melting surface has increased over the last two decades (photo: A.P. Ahlstrøm).
The Inuit of Greenland pursue the dual goals of becoming selfsupplying with energy and reducing their carbon dioxide $\left(\mathrm{CO}_{2}\right)$ emissions. This has made hydropower an attractive solution in Greenland, which is currently meeting the $\mathrm{CO}_{2}$ emission reduction goals specified in the Kyoto-protocol (Mai, 2007). Planning hydropower investments demand some degree of certainty as to the future variations in the availability of water. In Greenland, water is often glacial meltwater, and the hydropower feasibility is thus tightly linked to the fate of glaciers or ice sheet margins within the catchment. Several sites with hydropower potential in Greenland are currently being surveyed with respect to their future sensitivity to climate change, including one near the town of Ilulissat next to the famous Jakobshavn Isbræ, recently listed as a UNESCO World Heritage Site (Ahlstrøm, 2007).

Some mineral occurrences have been located just at the margin of the Greenland ice sheet, even extending beneath the ice. Given the history of extensive ice-marginal change in Greenland, prospective mining companies wish to know what risks they might be taking if they attempt to exploit such an occurrence. Specifically, they are interested in the expected ice-marginal increase in retreat rates as a function of climatic change and likely changes in the glacial meltwater routing that they will have to deal with.

The melting Arctic ice masses are clearly of global as well as regional concern. The Nordic geological surveys thus have an important role to play in assessing the impact of climate change on these and the assessing the consequences for society. Current projects connected with International Polar Year 2007-2008 address some of these issues (i.e., "Arctic Natural Climate and Environmental Changes and Human Adaptions"; www.ngu.no/SciencePub ).

\section{Geological data for society}

During the period of their existence, the Nordic geological surveys have generated a substantial amount of information on the Earth's crust, its natural resources, its processes, and on the geological history of Nordic areas. Their collective mission is to make this geological information and data easily accessible to all the varied end users in industry, government agencies, government institutes, public administrations, technical offices, academia and research institutes, as well as for private individuals. Traditionally, geological maps and technical reports have been the main products, but today the products provided by the surveys cover a large spectrum of geological, geophysical and environmental databases, maps, models, cores and geological samples, literature and internet-based news- and servicepages.

The formats and distribution protocols of geological data products have been jointly developed by the Nordic national communities and the EU (INSPIRE) spatial information community. Data distribution policy varies between the countries; consequently, in some of the surveys supply of selected information or materials is chargeable by law. Others have made the information available on an open access basis. The internet is currently being developed as the main distribution channel as it gives easy access to key information for all users. The accessible databases are updated continuously. Over the history of the Nordic surveys, and at present, securing the growing volumes of geological and environmental information has consistently proved to be efficient and economically advantageous for society.

\section{References}

Ahlstrøm, A.P., 2007, Previous glaciological activities related to hydropower at Paakitsoq, Ilulissat, West Greenland: GEUS Report 2007/25, 42 pp.

Ahlstrøm, A.P., van As, D., Citterio, M., Andersen, S.B., Fausto, R.S., Andersen, M.L., Forsberg, R., Stenseng, L., Christensen, E.L., and Kristensen, S. S., 2007, A new programme for monitoring the mass loss of the Greenland Ice Sheet: Eos Trans. AGU, 88 (52), Fall Meet. Suppl., Abstract (C11A-0083). 
Airo, Meri-Liisa (ed.), 2005, Aerogeophysics in Finland 1972-2004: Methods, System Characteristics and Applications: Geological Survey of Finland, Special Paper v. 39, 197 p., 8 apps.

Alley, R.B., Spencer, M.K., and Anandakrishnan, S., 2007, Ice-sheet mass balance: assessment, attribution and prognosis: Ann. Glaciol. 46, pp. 1-7.

Braathen, A., Blikra, L.H., Berg, S. S. and Karlsen, F., 2004, Rock-slope failures in Norway; type geometry, deformation mechanisms and stability: Norwegian Journal of Geology, v. 84, pp. 67-88.

Bøe, R., Longva, O., Lepland, A., Blikra, L.H., Sønstegaard, E., Haflidason, H., Bryn, P. and Lien, R., 2004, Postglacial mass movements and their causes in fjords and lakes in western Norway: Norwegian Journal of Geology, v. 84, pp. 35-55.

Børresen, A.K., and Wale, A., 2008, Kartleggerne, Norges geologiske undersøkelse 1858-2008, Tapir Akademiske Forlag, 351 pp.

Eysteinsson, H., Árnason, K., and Flóvenz, O.G., 1994, Resistivity methods in geothermal prospecting in Iceland: Surv. Geophy., v. 15, pp. 263-275.

Fridleifsson, G.O. and Elders, W.A., 2005, The Iceland Deep Drilling Project: a search for deep unconventional geothermal resources: Geothermics, v. 34, pp. 269-285

Fridleifsson, I.B., 2005, Twenty Five Years of Geothermal Training in Iceland: Proceedings of the World Geothermal Congress 2005, Anatalya, Turkey, $10 \mathrm{p}$.

Franzson, H., Kristjánsson, B.R., Gunnarsson, G., Björnsson, G., Hjartarson, A., Steingrímsson, B., Gunnlaugsson, E. and Gíslason, G. 2005, The Hengill-Hellisheidi Geothermal Field. Development of a Conceptual Geothermal Model: Proceedings of the World Geothermal Congress 2005, Anatalya, Turkey, 7 pp.

Harbitz, C.B., Løvholt, F., Pedersen, G., and Massson, D.G., 2006, Mechanisms of tsunami generation by submarine landslides: a short review: Norwegian Journal of Geology, v. 86, pp. 355-264.

Holthedal, H., 1993, Marine geology of the Norwegian continental margin: Nor. geol. unders., Special Publication, v. 6, pp.1-150.

Idman. H.,1994, Geology in urban planning - challenges and chances for geoscientific databases, in Wang, S. and Wang, C. (eds.), Geoscience in urban development: proceedings of the International Conference on Geoscience in Urban Development (LANDPLAN IV), 11-15 August 1993 Beijing, China: China Ocean Press, pp. 461-462.

Idman, H., Lintinen, P. and Nenonen, K, 2006, Application of geological maps in land-use planning in Finland, in 5th European Congress on Regional Geoscientific Cartography and Information Systems: earth and water, Barcelona, Catalonia, Spain, June 13th-16th 2006: proceedings. Vol. 1. Barcelona: Institut Cartogràfic de Catalunya, Institut Geològic de Catalunya, pp. 568-571.

Jarva, J. and Virkki, H., 2006, Dealing with natural hazards: practice in the Finnish spatial planning system, in Natural hazards and spatial planning in Europe. Dortmund: Dortmunder Vertrieb fr Bauund Planungsliteratur, pp. 19-36.

Kristmannsdottir, H., and Armannsson H., 1996. Geochemical monitoring of Icelandic geothermal fields during productions: Geothermics, v. 25 (3), pp. 349-364

Longva, O. and Thorsnes, T. (eds.), 1997, Skagerrak in the past and the present-an integrated study of geology, chemistry, hydrography and microfossil ecology: Nor. geol. unders., Special Publication, v. 8, pp $1-98$.

Mai, H., 2001, Oplæg til energiplan 2020: NIRAS Report, Greenland Home Rule, 37 pp.

Morfeldt, D. and Persson., L., 1997, Research and documentation on the importance of engineering geology in some underground projects, Stockholm, Sweden: Tunnelling and Underground Space Technology, USA. v. 12 (4), pp. 473-477

Neeb, P.-R. (ed.), 1996, Geological information for environmental and landuse planning in the Mid-Norden region: Geological Survey of Finland. Special Paper 22, pp. 19-23.

Neeb, P.-R., 2006. Mineral resources in Norway. The Norwegian mining and quarrying industry in 2005: NGU report 2006.048, 28 p.

Nenonen, K., Ristaniemi, O. and Kallio, P., 1999, Geological maps in town planning - a step towards sustainable development in Finland: Episodes, v. 22 (4), pp. 298-300.

Nikkarinen, M., Kauniskangas, E., and Nenonen, K., 1996. Use of geological and geochemical data for the derivation of maps for environmental planning in Isalmi, Finland, in Fuge, R., Billett, M. and Selinus, O. (eds.), Environmental geochemistry: selected papers from the 3rd Internationa Symposium, Kraków, Poland, 12-16 September 1994: Applied Geochemistry, v. 11 (1-2), pp. 261-270.

Nyberg J., Malmgren B.A., Winter A., Jury M., Kilbourne H. and Quinn T., 2007, Low Atlantic hurricane activity in the 1970's and 1980's compared to the last 270 years: Nature, v. 447, pp. 698-701.
Ojala, A., Vanhala, H., Palmu, J.-P., Ikävalko, O. and Lintinen, P., 2006 , Combining geophysical, sedimentological and geotechnical information to characterize geological history of Suurpelto construction site in Espoo, southern Finland, in 5th European Congress on Regional Geoscientific Cartography and Information Systems: earth and water, Barcelona, Catalonia, Spain, June 13th-16th 2006: proceedings. Vol. 1. Barcelona: Institut Cartogràfic de Catalunya: Institut Geològic de Catalunya, pp. 579-581.

Ottesen, D., Dowdeswell, J.A. and Rise, L., 2005, Submarine landforms and reconstructions of fast-flowing ice streams within a large Quaternary ice sheet: The 2500-km-long Norwegian-Svalbard Margin $\left(57^{\circ}-80^{\circ} \mathrm{N}\right)$ : Geol. Soc. Am. Bull., v. 117, pp. 1033-1050.

Persson, L., 2002, Rock materials for construction, in J.L. van Rooy and C.A. Jeremy, Eds, 9th IAEG Congress, Curban, South Africa: Engineering Geology for Developing countries, pp. 65-81.

Persson, L., 1998, Engineering geology of Stockholm, Sweden: Bulletin of Engineering Geology and the Environment, v. 1, pp. 79-90.

Persson, L., and Schouenborg, B., 1996, Quality classification of rock in Sweden. European Aggregates: Official Journal of UEPG, 2-3.

Puranen, R.; Sahala, L., Säävuori, H., and Suppala, I., 1999. Airborne electromagnetic surveys of clay areas in Finland, in Autio, S., ed., Geological Survey of Finland, Current Research 1997-1998: Geological Survey of Finland, Special Paper 27, pp. 159-171.

Rise, L., Ottesen, D., Berg, K. and Lundin, E., 2005. Large-scale development of the mid-Norwegian shelf and margin during the last 3 million years: Marine and Petroleum Geology, v. 22, pp. 33-44.

Rise, L., Ottesen, D., Longva, O., Solheim, A., Andersen, E.S. and Ayers, S., 2006, The Sklinnadjupet slide and its relation to the Elsterian glaciation on the mid-Norwegian margin: Marine and Petroleum Geology, v. 23, pp. 569-583.

Schmidt-Thome, P., (ed.), 2006, Natural and technological hazards and risks affecting the spatial development of European regions: Geological Survey of Finland. Special Paper 42. Espoo: Geological Survey of Finland. $167 \mathrm{p}$.

Schmidt-Thome, P., 2006, Integration of natural hazards, risk and climate change into spatial planning practices, Espoo: Geological Survey of Finland, v. 31, 93 p.

Schmidt-Thome, P., Greiving, S., Kallio, H., Fleischhauer, M. and Jarva, J. 2006, Economic risk maps of floods and earthquakes for European regions, in Impact of rapid environmental changes on humans and ecosystems: Quaternary International, v. 150, pp. 103-112.

Selonen, O., and Suominen, V., Eds., 2003, Nordic Stone: Geological Science series, UNESCO Publishing.

Smelror, M., Dehls, J., Ebbing, J., Larsen, E., Lundin, E.R., Nordgulen, Ø., Osmundsen, P.T., Olesen, O., Ottesen, D., Pascal, C., Redfield, T.F., and Rise, L., 2007, Towards a 4D topographic view of the Norwegian Sea margin: Global and Planetary Change, v. 58, pp. 382-410.

Stefansson, V., Axelsson, G., Sigurdsson, O., and Kjaran, S.P., 1995. Geothermal reservoir management in Iceland. Proceedings of theWorld Geothermal Congress 1995, Florence, Italy, pp. 1763-1768.

Thorsnes, T. and Fosså, J.H., 2004, Deep-water Coral Reefs. Acoustic recognition and geological setting, Hydro International, v. 8, pp. 26-29.

Trenberth, K.E., Jones, P.D., Ambenje, P., Bojariu, R., Easterling, D., Klein Tank, A., Parker, D., Rahimzadeh, F., Renwick, J.A., Rusticucci, M., Soden, B., and Zhai, P., 2007, Observations: Surface and Atmospheric Climate Change, in Solomon, S., Qin, D., Manning, M., Chen, Z., Marquis, M., Averyt, K.B., Tignor M., and Miller H.L. (eds.), Climate Change 2007: The Physical Science Basis, Contribution of Working Group I to the Fourth Assessment Report of the Intergovernmental Panel on Climate Change: Cambridge University Press, Cambridge, United Kingdom and New York, NY, USA.

Viberg, L., Fallsvik J. and Johansson K., 2002, National map data base on landslide prerequisites in clay and silt areas-development of prototype, in McInnes, R.G. AND Jakeways, J. (eds.), Instability-Planning and Management. Proceedings of the international conference organised by the Centre for the Coastal Environment, Isle of Wight Council, and held in Ventor, Isle of Wight UK om 20-23rd May 2002, 407-414: Thomas Telford, London.

Wennerström, M., Airo, M-L., Elminen, T. and Pajunen, M., 2006. Tectonic evolution as the basis in urban bedrock mapping in the Helsinki area southern Finland, in 5th European Congress on Regional Geoscientific Cartography and Information Systems: earth and water, Barcelona, Catalonia, Spain, June 13th-16th 2006: proceedings. v. 1. Barcelona: Institu Cartogràfic de Catalunya: Institut Geològic de Catalunya, pp. 624-625. 
Morten Smelror is General Director of the Geological Survey of Norway (NGU). After graduating from the University of Oslo in 1985 he has held several research and management positions at SINTEF Petroleum Research Ltd. and Norwegian University of Science and Technology, before the joined NGU in year 2000. His research interests include paleontology, stratigraphy and exploration geology of the Norwegian Continental Shelf and the Arctic.

Andreas P. Ahlstrøm is a glaciologist at the Geological Survey of Denmark and Greenland (GEUS) where he heads the Danish programme for monitoring of the Greenland ice sheet and carries out research on glaciers and ice sheets in a changing climate. He holds a MSC in geophysics (1999) and a PhD in physical geography (2003) from the University of Copenhagen and worked at the Technical University of Denmark as assistant professor before starting in 2006 at the Geological Survey of Denmark and Greenland.

Lena Ekelund is Director at the Geological Survey of Sweden (SGU). From 1996 to 2004 she was responsible for building up the Customer Services function, for which she also has been the manager. From 1985 she was State Geologist at the department of Environment and Geochemistry, working with the national biogeochemical mapping programme and environmental geochemistry.

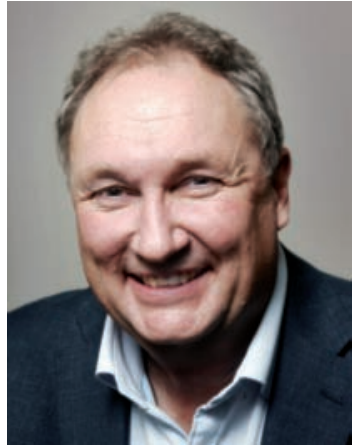

Jens Morten Hansen is State Geologist at the Geological Survey of Denmark and Greenland (GEUS) and adj. professor of natural philosophy at Copenhagen University since. From 1998 to 2006 he was director for the Danish Research Agency and Research Councils. From 1990 to 1998 he was vice managing director at GEUS and centre leader of the Ground Water Group under the national programme for environmental research.

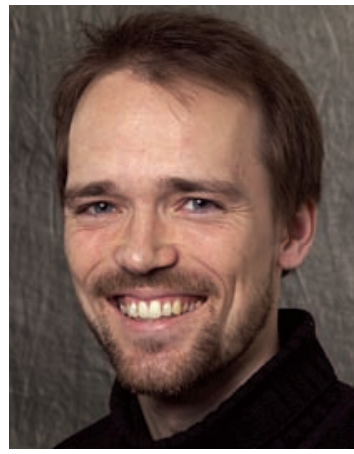

Keijo Rainer Nenonen is a professor and research director at the Geological Survey of Finland (GTK) in the field of Quaternary Geology and Environment. He is contact person in the Inter-Nordic MidNorden projects and Euro-GeoSurvey (Co-operation unit of the European Geological Surveys, Brussels). He started his 30 years long career at GTK in 1974 assisting in ore prospecting services in Lapland to managing and directing roles in Kuopio and Espoo. Nenonen has published more than 100 papers in the field of Quaternary stratigraphy, engineering and environmental geology, and land-use planning.

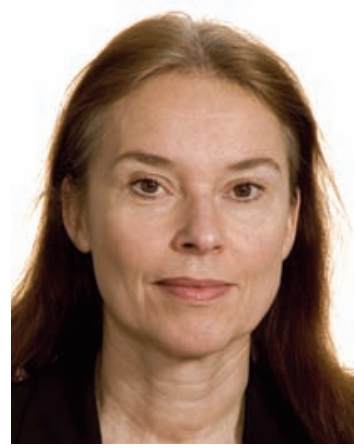

Anette K. Mortensen is a geologist at Iceland Geosurvey (ÍSOR), where she is working on the geology and hydrothermal alteration in geothermal areas. She graduated from Aarhus University in 2000 and after a stay at Nordic Volcanological Institute, Iceland, she has since 2005 been working at Iceland Geosurvey.
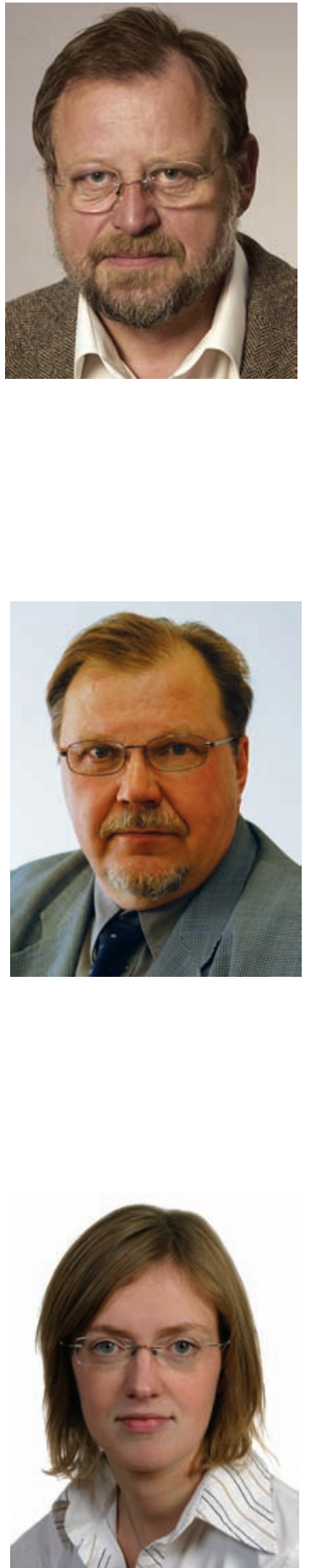